\title{
An Evaluation of Financial Literacy in Elementary Schools towards Financial Education Enhancement: A Case Study of Baltimore Public Schools
}

\author{
Michael Elonge \\ University of Maryland (College Park) Extension in Maryland, USA
}

\begin{abstract}
Financial literacy education has traditionally never been a major subject area in most public schools in Maryland. With the unanticipated struggling of the United States of America (USA) Economy, Maryland (one of the richest states in the USA and its residents, especially of its major urban city, Baltimore, is facing severe family and personal financial crisis. This unanticipated financial crisis characterized by declining family and personal savings, mortgage defaults and foreclosures, and tenant evictions due to rent defaults is motivating educators, business entities, and politicians to develop education strategies to educate children from future financial crisis. Although there is an overwhelming consensus for providing financial education as a major curriculum to our schoolchildren, the practicability of most curriculums is obscure. To develop a practical approach to teaching financial literacy in elementary schools, an assessment using a Grid Familiarity Rating Chart (Very Familiar - Not Familiar) of basic financial and economics concepts was assigned to 210 students (4th -5 th graders) in four inner city schools. Students received information to place a check mark by each concept if they are very familiar or familiar with the concept. Results revealed that $97 \%$ of the students were very familiar or familiar with the basic financial concepts as compared to $49 \%$ of the students who were very familiar or familiar with basic economic concepts. Even when students were encouraged to explain their very familiar or familiar concepts, $80 \%$ provided explanations that were accurate or almost accurate for basic financial concepts as compared to $20 \%$ accuracy for explanations with basic economic concepts. Conclusively, the most basic economic concepts (scarcity, choice, and opportunity cost), which are essential decision making tools for most financial decisions should be simplified and included in financial education lesson plans.
\end{abstract}

\section{Introduction}

Since the year 2000, the growing importance and emphasis of financial literacy and financial education in the United States of America (USA) has been phenomenal. The recent USA financial crisis was a revelation to the low level of financial literacy in USA [3]. When financial literacy education is missing from childhood, the impact could lead to perplexity in adulthood in relating to the economy [7]. Exemptions could be luck based on parental influence in modeling financial literacy in the upbringing of children, which could lead to mastering of positive financial behaviors in adulthood [6]. There are nationally recognized programs hailed by the USA Federal Reserve System as exemplary efforts to promote youth finance education in the USA [2]. Ironically, a predominate majority of inner city schools in the USA do not have elementary school teachers with high levels of financial literacy and aptitude to teach students [1]. As literature on financial literacy suggests, financial literacy has never been a scholarly distinct field in the academia of the USA. Consequently, conceptualizing financial literacy to create teachable moments is tantamount to isolating and simplifying tangible financial concepts, traditionally embedded in the field of economics to derive financial or money management concepts (Earning, Spending, Saving, Investment, Sharing, Credit, Debt, etcetera). In such a circumstance, it would be misleading to teach financial literacy especially in elementary schools without tapping into the foundation of economics, key principles of economics (scarcity, choice and opportunity cost), which are essential decision making tools in the economy [9]. Integrating these concepts in teaching would require teachers to be creative and practical in developing elementary mindsets with a lifetime financial literacy aptitude to deal with unanticipated financial challenges [5]. Teaching children piggy banking or couponing is great, but teaching basic economic decision-making processes that underpins piggy banking or couponing develops a lifetime understanding of financial literacy. This paper is a case study that was done to evaluate financial literacy in inner city elementary schools in Baltimore, Maryland, and to develop a practical approach to teaching financial literacy that differentiates and edifice basic financial and economic concepts into action-oriented learning [8].

\section{Methodology}

To understand elementary school students' knowledge of financial literacy, a brief survey, Grid Rating Familiarity Chart of basic financial and economic concepts in random order, were assigned to 210 elementary school students in Baltimore City 
public school system. Students participating in the survey were 4th and 5th grade students from four different inner city schools. There was no need to separate the 4th from the 5 th graders, because all the students had no prior exposure to a formal business, economics, finance, or family consumer science teacher.

Table 1. Grid Familiarity Rating Chart

\begin{tabular}{|l|l|l|l|l|}
\hline Concepts/Ideas & $\begin{array}{l}\text { Very } \\
\text { Familiar }\end{array}$ & Familiar & $\begin{array}{l}\text { Less } \\
\text { Familiar }\end{array}$ & $\begin{array}{l}\text { Not } \\
\text { Familiar }\end{array}$ \\
\hline Saving & & & & \\
\hline Debit Cards & $\checkmark$ & & & \\
\hline Credit Card & $\checkmark$ & & & \\
\hline Scarcity & & & & \\
\hline Spending & & $\checkmark$ & & \\
\hline Choice & & & & \\
\hline Preference & & & & \\
\hline Substitutes & & & & \\
\hline Earning & & & & \\
\hline Opportunity Cost & & & & \\
\hline Price & & & & \\
\hline Demand & & & & \\
\hline
\end{tabular}

Students informed by their school to volunteer in doing activities to help this evaluator design a lesson plan that would be beneficial to them and most elementary school students. Students received explanation of the meaning of concepts (ideas) and familiarity. Students were to place a checkmark for each concept under the header options: Very Familiar, Familiar, Less Familiar or Not Familiar; to indicate their familiarity with the concept. Students were told that each of them will be given an opportunity to tell and explain their Very Familiar and Familiar concepts to the class and how they knew about the concept. Students also received information not to write their names on the Grid Familiarity Rating Chart. Regular classroom teachers of the students were facilitators in this process, which also helped to make students comfortable and cooperative in doing the activity.

There was a show and tell aspect where students would show the class their very familiar concepts and briefly tell (explain) their familiarity with the concepts. The evaluator, using the evaluator's copy of the Grid Familiarity Rating Chart would place a check mark to indicate a perfect or almost perfect explanation or zero check mark for any unrelated explanations to a concept. The evaluator's check mark is an affirmation that the student understands the concept. This process made it easier for the evaluator to tally the numbers of checkmarks under familiarity options.

\section{Data from Grid Familiarity Chart}

Data from 210 students indicated that there were no significant differences in familiarity of concepts between the four different schools. The aggregate data of all four elementary schools, based on checked concepts and explanation, indicated that a majority of students were Very Familiar with Savings, Credit Card, Spending, Earning, and Price.

Familiar with Debit-Cards, Preference, and Supply Less Familiar or Not Familiar with Scarcity, Choice, Substitutes (to some, this was substitute teachers) and Opportunity-Cost.

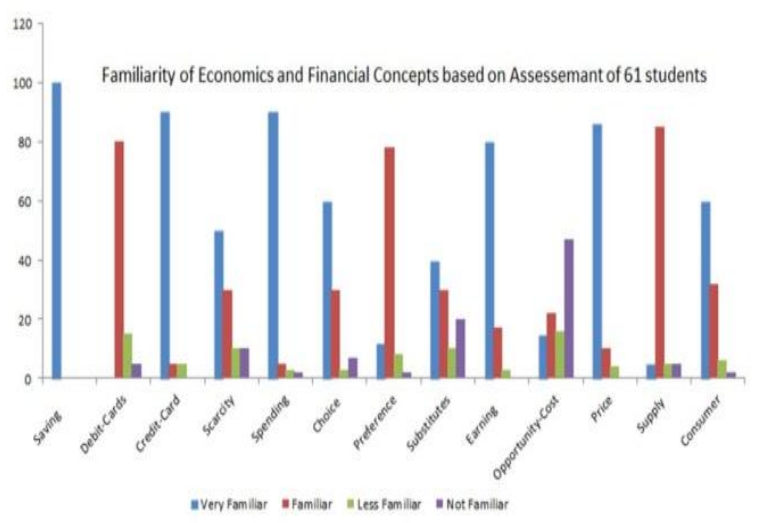

Figure 1. Aggregate Data of All Four Schools

\section{Outcome}

On the aggregate, $97 \%$ of the students were Very Familiar or Familiar with the basic financial concepts as compared to $49 \%$ of the students who were Very Familiar or Familiar with basic economic concepts (Figure 2).

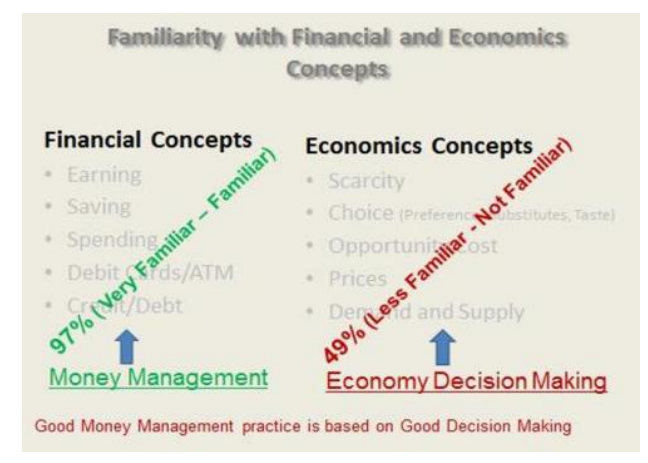

Figure 2. Familiarity with Concepts

In the explanation of concepts, $80 \%$ provided answers that were accurate or almost accurate with the basic financial concepts as compared to $20 \%$ accuracy in explanation of economic concepts.

Economic concepts are decision-making concepts. The key concepts (Scarcity, Choice and Opportunity Cost) seem abstract, but learnable. The concepts are the core principles guiding decision making in the economy. To function in the economy, effectively, people need to learn how to use these concepts to make concrete decisions in the 
economy. Good money management practice is a function of good decision making based on the understanding of scarcity, choice and opportunity cost.

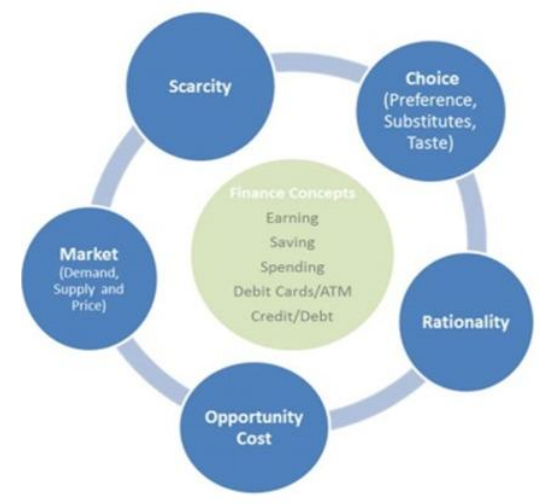

Figure 3. Economic Concepts controls Financial Concepts

Economic concepts and financial concepts are interdependent (Morton, 2005). In context, the interdependence of economics and financial concepts could be as follows:

- Money management is a practical application of concepts encapsulated in the study of economics.

- In every introduction to economic textbooks, money is a major topic and not the introductory topic.

- The introductory topics are usually principles of economics.

- Therefore, it makes sense to first, teach the elementary students to master principles of economics to make money management a routine based on concrete decision-making.

- After all, economic concepts are decisionmaking techniques for the economy that affect any financial concepts or financial decisions as symbolized pictorially (Figure 3).

\section{Implication}

This case study has implications for both instructional design and teachers of financial literacy. Inner city elementary school students' knowledge of financial literacy concepts was overwhelmingly high as compared to economic concepts. However, they were deficient in relating to basic economic concepts that are central in decision making, even at the basic level.

Instructional designers should recognize the interdependency of economic and personal finance, when designing a financial literacy curriculum. The most basic economic concepts (scarcity, choice, and opportunity cost) should be simplified and included in lesson plans as decision making tools for most financial literacy concepts (earning, spending, saving, sharing, credit/debt, and banking).

When teaching financial literacy, elementary school teachers should teach basic economic concepts in a creative and practical manner such that students can master, practice, and relate economic concepts (decision-making concepts) to money management and the economy as a whole.

If teachers and educators teach elementary school students to become very familiar with this teaching approach, students would be able to apply these concepts to make concrete decisions with money over time.

\section{A Program Example}

Learning and Practicing Basic Economics and financial principles: The Arts of Money

Management is a University of Maryland Extension program for elementary school students (grades $4-5$ ) in schools with no business, economics, and finance teachers.

The objective of this program is to enable students to develop concrete understanding of money and skills in money management by learning and practicing basic economic and financial principles.

Program Sections: This program has three sections: section-1, learning and practicing of basic financial principles; section-2, the teaching and application of basic economics; and section-3, teaching and practice the arts of money management in using a market scenario.

Section 1: The learning and practicing of basic financial principles using activities:

Icebreaker: The teaching of every section begins with an icebreaker (usually a money video clip from You-tube) and then, a word search puzzle.

Financial Word Search Puzzle: Students learn start learning basic principles using a word search puzzle. 


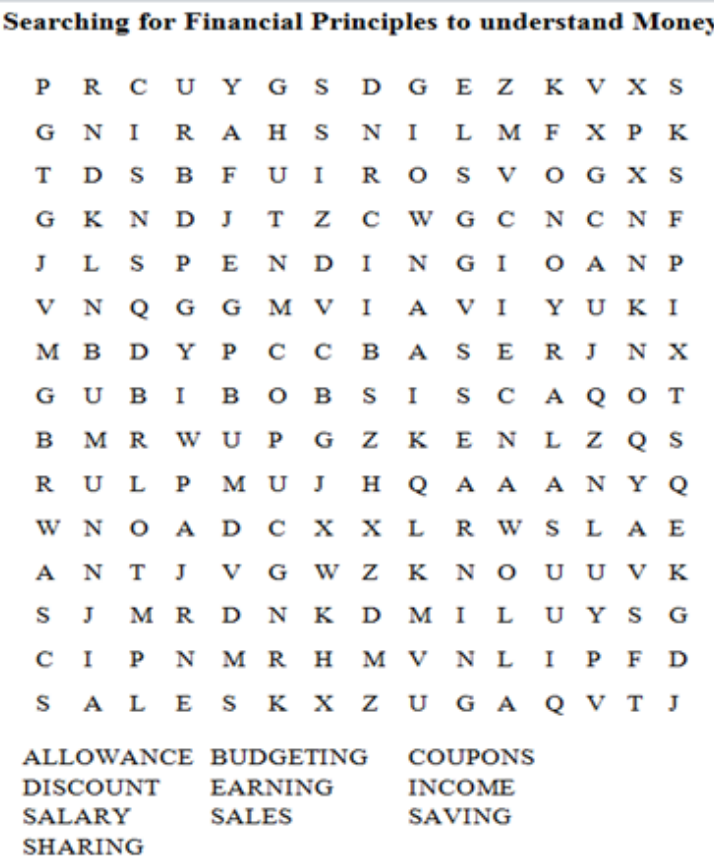

Figure 4. Financial Principles Puzzle

Matching principles to definitions: In another activity, teacher asks students to match financial principles by placing the alphabet of the appropriate meaning by each principle.

Earning

Income

Allowance

Salary

Budgeting

Saving

Spending

Sales

Sharing

a. Giving some of your money to others

b. Money received for working at home.

c. Amount of Money offered to be paid per year for working

d. Money earned for working.

e. Money not saved

f. Constant money I get for working.

g. A plan to manage money

h. When I spend less money for something than the original price

i. Money I put in a Bank
Table 2. A summary of Activities in section 1

\begin{tabular}{|c|c|}
\hline Topics & Activities \\
\hline $\begin{array}{l}\text { Financial Principles } \\
\text { - Earning } \\
\text { - Income } \\
\text { Allowance } \\
\text { Salary } \\
\text { - Budgeting } \\
\text { - Saving } \\
\text { - Spending } \\
\text { Sales } \\
\text { Discount } \\
\text { Coupons } \\
\text { - Sharing }\end{array}$ & 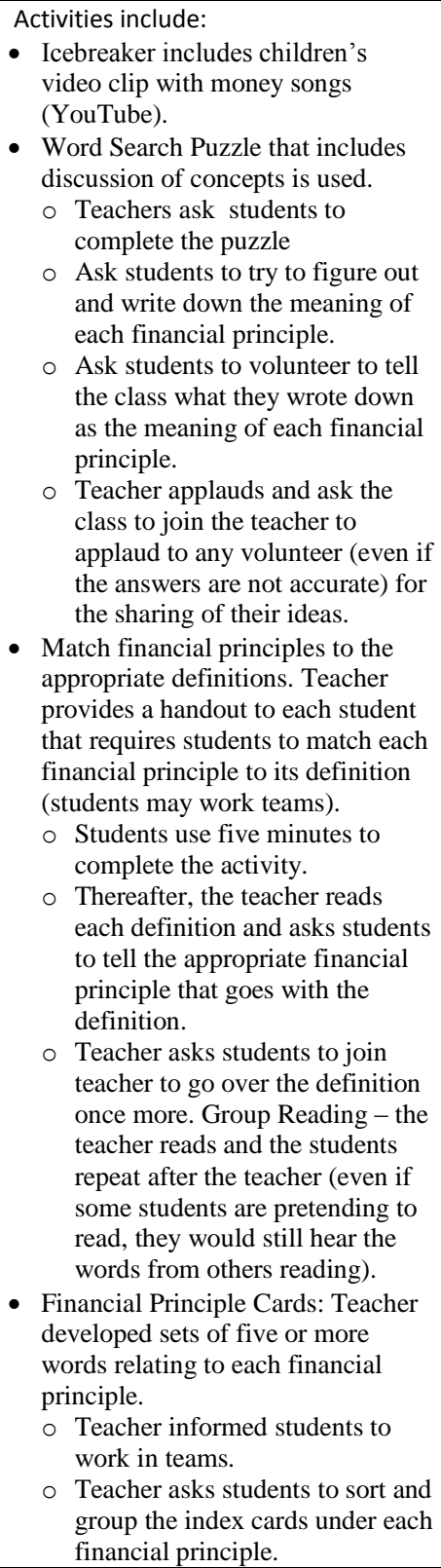 \\
\hline
\end{tabular}

After teaching students to learn and practice basic financial principles at a comfort level (students can quickly remember the various principles and their significance), the program proceeds to section 2 .

Section 2: Learning and practicing of basic economics principles.

This section use similar activities as in section 1

The objective is to teach students to learn and practice basic economics principles with activities: Economics Puzzle: This activity is to help students learn basic economics principles and to get familiar with the principles. 


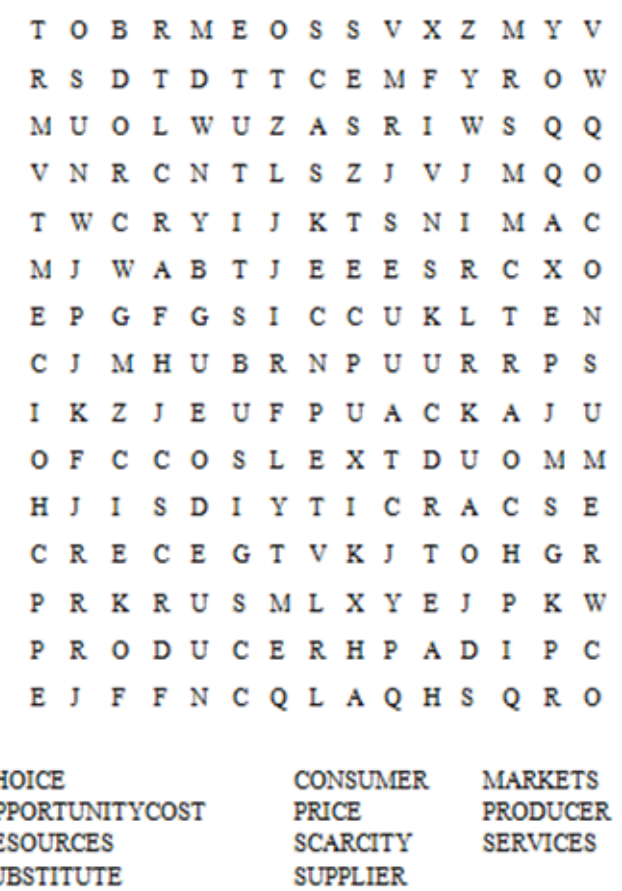

Figure 5. Economics Principles for Decision-making

Know it or Guess it

This activity is to figure out what students may know about each economic principle: I have recognized that most grades 4-5 students are very cleaver. Before explaining each principle, I gave students the opportunity to tell the group if they know the meaning of any of the concepts.

Table 3. Exploring meaning of principles

\begin{tabular}{|l|l|}
\hline Words & Guess the meaning or give examples \\
\hline Producers & \\
\hline Resources & \\
\hline Goods & \\
\hline Services & \\
\hline Substitute & \\
\hline Consumers & \\
\hline Suppliers & \\
\hline Price & \\
\hline Scarcity & \\
\hline Choice & \\
\hline Opportunity Cost & \\
\hline Markets & Guess the meaning or give examples \\
\hline Words & \\
\hline Producers & \\
\hline Resources & \\
\hline Goods & \\
\hline Services & \\
\hline Substitute & \\
\hline Consumers & \\
\hline Suppliers & \\
\hline Price & \\
\hline Scarcity & \\
\hline Choice & \\
\hline Opportunity Cost & \\
\hline Markets & \\
\hline
\end{tabular}

Reinforcing the learning: After students fumble with the Know it or Guess it activity, the teacher provides handouts of definition to students. The teacher reinforces the learning of economics principles by reading each one of them and asking the class to follow like a chorus.
Interestingly, even students who do not like reading are motivated to be a part of the chorus; and those do not want to read would hear the words anyway.

Producers: Are people and firms that use resources to make goods and services.

Example: Hersey is a producer of Chocolate

Resources: Are things that a producer needs to produce goods and services.

The three (or four) basic kinds of resources used to produce goods and services: land or natural resources, human resources

(including labor and entrepreneurship), and capital.

Goods: Are things that we want to use. Examples include food items or outfits.

Services: Are things that we want other people to do for us.

Examples include school providing us with a school bus taking us to school and dropping us home, mail carrier delivering our mail, and pizza delivery to your home.

Substitute: A good or service that may be used in place of another good or service; examples include tap water for bottled water (or vice versa) and Pepsi for Coke (or vice versa).

Consumers: People who use goods and services to satisfy their economic wants

Suppliers: People who supply or sell goods and services to make money

Price: Is the amount of money that people pay when they buy a good or service; the amount they receive when they sell a good or service.

Scarcity: is when goods and services are limited, not enough for everyone who wants them. A good example is money.

Choice: The decisions people make when there is scarcity.

Example: If my allowance (my money) is limited and my choice is to spend it, then I will not be able to save it.

Figure 6. Economics principles and definitions 
Table 4. Summary of topics and activities in Section 2

\begin{tabular}{|c|c|}
\hline Topics & Activities \\
\hline $\begin{array}{l}\text { Economics } \\
\text { Principles } \\
\text { Resources } \\
\text { - Scarcity } \\
\text { - Choice } \\
\text { Preference } \\
\text { Substitute } \\
\text { Rationality } \\
\text { - Opportunity Cost } \\
\text { - Market } \\
\text { Buyers } \\
\text { Consumers } \\
\text { Demand } \\
\text { Needs } \\
\text { Wants } \\
\text { Producers } \\
\text { Suppliers } \\
\text { Supply } \\
\text { Price } \\
\text { Goods } \\
\text { Services }\end{array}$ & $\begin{array}{l}\text { Activities include: } \\
\text { - Icebreaker includes children's } \\
\text { video clip with money songs } \\
\text { (YouTube). } \\
\text { - Word Search Puzzle that includes } \\
\text { discussion of economics principles } \\
\text { used. } \\
\text { - Teacher asks students to } \\
\text { complete the puzzle } \\
\text { - Ask students to try to figure out } \\
\text { and write down the meaning of } \\
\text { each economic principle. } \\
\text { Ask students to volunteer to tell } \\
\text { the class what they wrote down } \\
\text { as the meaning of each } \\
\text { economic principle. } \\
\text { Teacher applauds and asks the } \\
\text { class to join the teacher to } \\
\text { applaud to any volunteer (even } \\
\text { if the answers are not accurate) } \\
\text { for the sharing their ideas. } \\
\text { - Match economics principles to the } \\
\text { appropriate definitions. Teacher } \\
\text { provides a handout to each student } \\
\text { that requires students to match } \\
\text { each economic principle to its } \\
\text { definition (students may work } \\
\text { teams). } \\
\text { O Students are given five minutes } \\
\text { to complete the activity. } \\
\text { Thereafter, the teacher reads } \\
\text { each definition and asks } \\
\text { students to tell the appropriate } \\
\text { economic principle that goes } \\
\text { with the definition. } \\
\text { - Teacher asks students to join } \\
\text { teacher to go over the definition } \\
\text { once more. Group Reading - the } \\
\text { teacher reads and the students } \\
\text { repeat after the teacher (even if } \\
\text { some students are pretending to } \\
\text { read, they would still hear the } \\
\text { words from others reading). } \\
\text { - Economic Principle Cards: } \\
\text { Teacher develops sets of five or } \\
\text { more words relating to each } \\
\text { economics principle. } \\
\text { Teacher groups students into } \\
\text { teams. } \\
\text { Teacher asks students to sort } \\
\text { under each economics } \\
\text { principle. }\end{array}$ \\
\hline
\end{tabular}

Section - 2: A Summary

\section{A Review of Economics and Financial Principles (Section-1 and Section-2)}

Reviewing the economic and financial principles helps place emphasis on critical principles that students should remember and practice frequently. A student who may not like monotonous activities still enjoys puzzles, even if previously discussed.

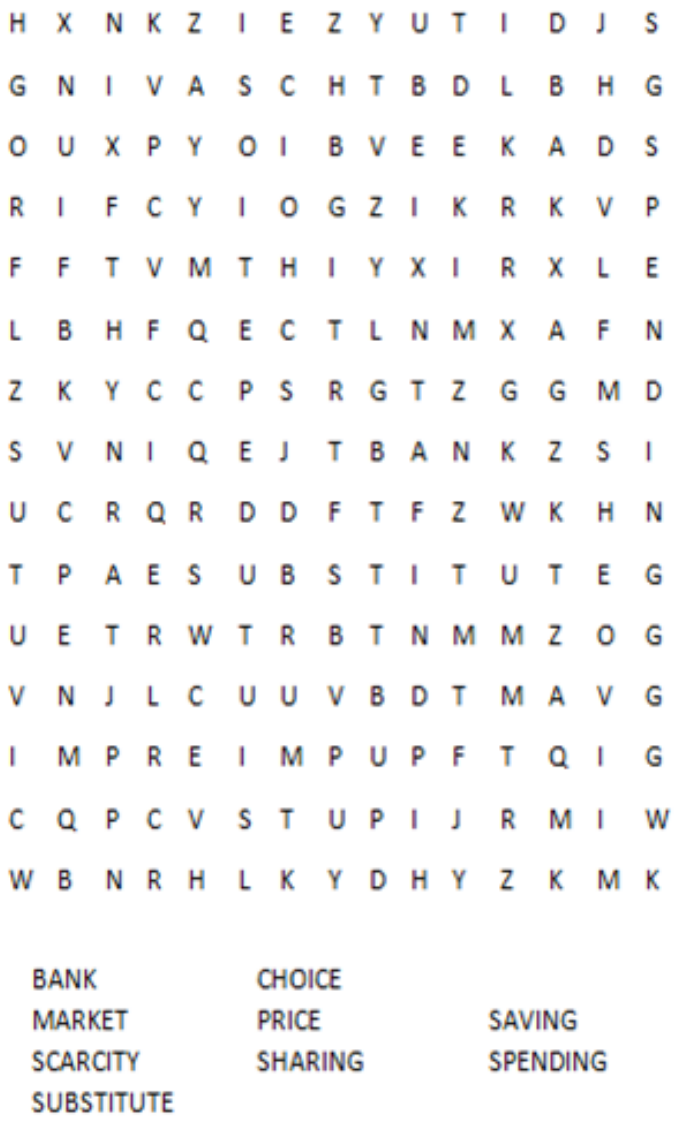

Figure 7. Review of Basic Economics and Financial Principles

Section 3: learning and practice the arts of money management in using a market scenario.

The third section teaches money and basic market system (detail discussions on the function and demand for money are not discussed. This is to avoid confusing the students (4th -5 th graders). Students understand that money is what you need to buy almost anything you want.

Earning money is a good thing. Most children earn money (allowance) by completing chores or from garage sales or selling lemonade on a lemonade stand.

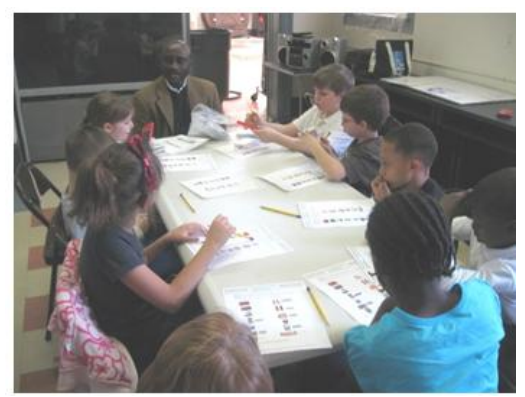

Figure 8. Educator and 4th grade students 


\section{Students Practice as Suppliers/Sellers}

Activity: The following activity helps students think about earning money (decision-making about pricing).

If you were a Supplier, a Boy Scout or Girl Scout, selling these items: how much would you price them

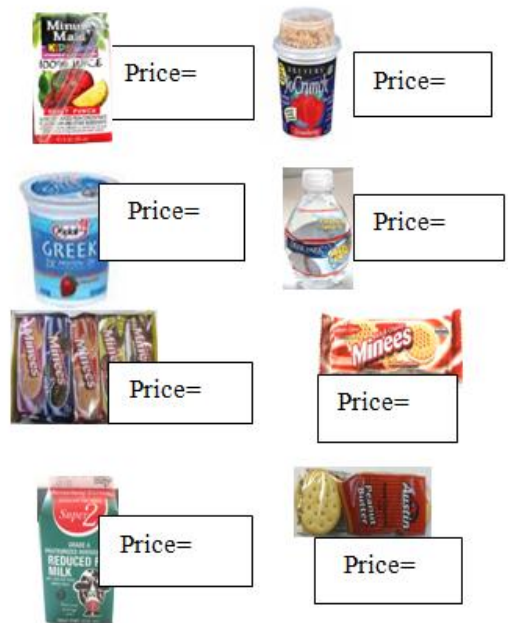

- Place your selling price in the price box.

- What is your total Sales \$

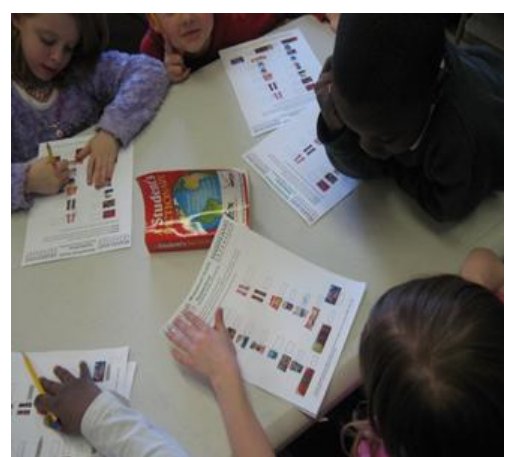

Figure 9. Students Practice as Consumers

Consumer Activity: The following activity helps students think about spending money (decisionmaking about spending).

If you are a consumer how much would you pay for the following items?

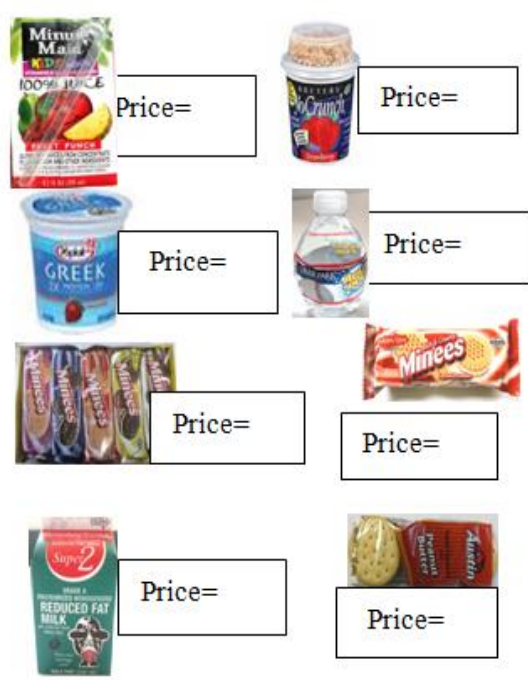

This consumer activity always creates pricing confusion to students. This is because students recall that they were previously selling the same items, as suppliers at a higher price than they themselves are will to pay as consumers. Educator facilitates the process by explaining to students that these are all money management decisions that both suppliers and consumers encounter in the market and everyday activities. Consumers are always willing to buy at the lowest price, while suppliers are always willing to sell at the highest price.

\section{Scarcity, Choice, Opportunity Cost and Money Activity}

Educator assigns the same list of items to students. Educator asks students:

- If you were given $\$ 3.00$ each, what items would you buy?

- Students worked individually to figure out what they could buy for $\$ 3.00$.

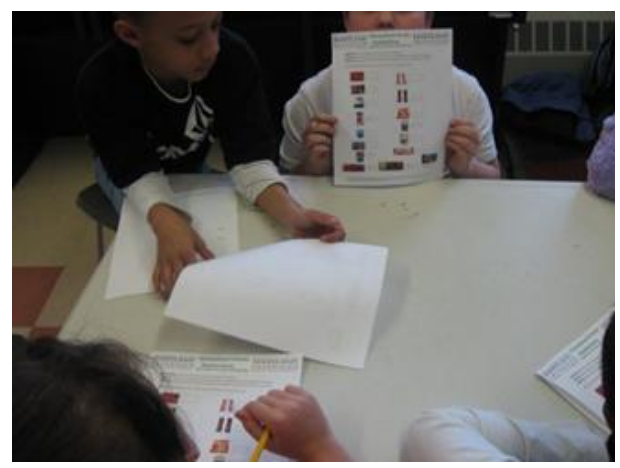

Educator realized that most students had four or more choice items that they could buy for $\$ 3.00$ (Students were making decisions based on their expectations of the value of their $\$ 3.00$ )

These items are real goodies, hidden behind a display board, at the back end of the classroom not revealed to the students. 
This time however, the Educator informed the students that what they intended to buy with their $\$ 3.00$ are available right here in the classroom.

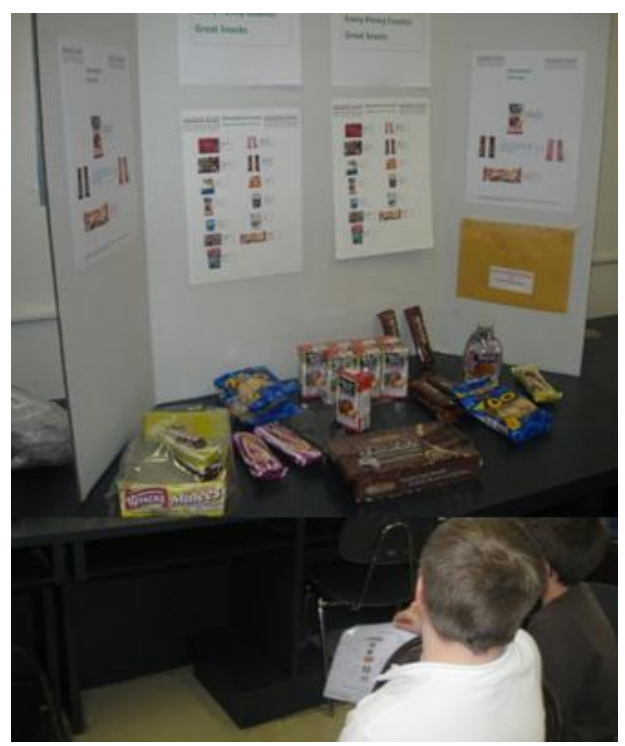

The display board was turned and all the goodies became visible, with the inscription - Welcome to the University of Maryland Extension Healthy Snacks Store - "Please check our price list for any item you want to buy"

\section{Decision-making problems to students}

- Scarcity of Money: Store prices were higher than anticipated prices such that most students could only afford one popular item such as Juice or Animal Crackers, and not both (Scarcity, Choice and Opportunity Cost).

- Scarcity of Goods: Some items such as Milk and Yogurt were sold-out in the Store.

Without instructions from the Educator, most students started reviewing their choices to get the most out of their $\$ 3.00$ (decisions making with money).

\section{Saving incentive}

In the Healthy Snacks Store, there is an envelope symbolizing a Bank - For any $\$ 50$ saved at the UME Bank, you get 25-cent by the next class and for every $\$ 1$ you get 50 -cent by the next class (Savings and Interest).

\section{Goodwill}

In the Healthy Snacks Store, there is also a Salvation Army drop box - Your Contribution Helps Us Feed the Homeless (Sharing)
Due to limited income, students reviewed their list to evaluate if the item to buy is a need or a want (decision-making with limited income).

Students were more attracted to the Bank rate and most students saved up to $\$ 1$ in anticipation of getting $\$ 1.50$ (interest) - the opportunity cost of spending

\section{Program Outcome}

In 2011, 618 (4th and 5th graders) six Baltimore City elementary schools participated in the program and in 2012 the program was extended to 211 students from two elementary schools in Baltimore County. Data collected from pre/post survey in 2013 indicates that:

- $89 \%$ of the 829 students (2011 - 2012) acquired new knowledge in basic economics (scarcity, choice, and opportunity cost) and money management.

- $86 \%$ of the students increased understanding of basic decision making with money.

- A teacher in one inner city school revealed that homework assignments completion rate increased by more than $50 \%$ during and after the program.

\section{Program Implication}

This program continues to be in demand by schools in Baltimore. Economics and financial principles are real concepts and it makes sense to teach these concepts using concrete activities despite the cost of materials involved in the program.

\section{Reference}

[1] R. C. Atchley, "Educating the public about personal finance: A call for action". Journal of American Society of CLU \& ChFC, 52(28), 30-32, 1998.

[2] B. Bernanke, "Financial literacy," Testimony before the Committee on Banking, Housing, and Urban Affairs of the United States Senate on May 232006.

[3] J. Campbell, "Household finance" The Journal of Finance, 61, 1591-1604, 2006.

[4] N. Chiteji, and F. Stafford, "Portfolio Choices of Parents and Their Children as Young Adults: Asset Accumulation by African American Families" American Economic Review Papers, 1999.

[5] L. M. Jakubowski and P. Burman, "Teaching Community Development: A Case Study in CommunityBased Learning." Teaching Sociology 32(2):160-76, 2004.

[6] A. Lusardi, and O. Mitchell, "Planning and Financial Literacy: How Do Women Fare?" American Economic Review 98(2), pp. 413-417, 2008. 
[7] L. Mandell, and K. Hanson, "The impact of financial education in high school and college on financial literacy and subsequent financial decision making". Paper presented at the American Economic Association Meeting, San Diego, CA. 2009.

[8] L. A. Mooney, and B. Edwards, "Experiential learning in Sociology: Service learning and other community-based learning initiatives" Teaching Sociology, 29(2), 181-194. 2001.

[9] J. S. Morton, "The interdependence of economic and personal finance education" Social Education, 69(2), 66$69,2005$. 